\title{
SISTEM PEMBERIAN KOMPENSASI DALAM MENINGKATKAN KINERJA DOSEN DI SEKOLAH TINGGI AGAMA ISLAM MA'ARIF SAROLANGUN
}

\author{
Norainun \\ STAI Ma'arif Sarolangun Jambi \\ Email : nurainon51@gmail.com
}

\begin{abstract}
Compensation is income in the form of money or goods either directly or indirectly, as a service fee for lecturers who are paid according to workload compentation is given aiming at increasing the motivation of lecturer performance. This journal research uses naturalistic quantitative method, the data collections using interview, observation and documentation technques. The results of this research of: 1) compensation received by STAI Ma;arif Sarolangun lecturers, in the form of teaching fees, testing, guiding fieldwork practices and community service. 2) there is not compensations in the form of goods given as awards for lecturers achievements. 3) compensations payment system lecturers STAI Ma'arif Sarolangun according to procedure, but the nominal is still very low when compared to compensation lecturers in Islamic college in the region KOPERTAIS XIII the Jambi Province.
\end{abstract}

Keywords: Compensation Payment, Lecturers Performance.

\begin{abstract}
Abstrak
Kompensasi adalah semua pendapatan baik yang berbentuk uang, barang langsung atau tidak langsung yang diterima dosen sebagai imbalan atas jasa. Maka dari itu, pemberian kompensasi dosen di bayar sesuai dengan beban kerja dosen dengan tujuan pemberian kompensasi (balas jasa) untuk meningkatkan motivasi kerja dosen. Meodologi yang digunakan dalam penelitian jurnal ini adalah kualitatif naturalisik, pengumpulan data menggunakan teknik wawancara, observasi dan dokumentasi. Hasil penelitian ini adalah: 1) bentuk kompensasi yang diterima oleh dosen STAI Ma'arif Sarolangun yaitu kompensasi honor mengajar, menguji, membimbing mahasiswa PPL dan kukerta. 2) belum ada kompensasi yang berbentuk barang sebagai penghargaan kepada dosen yang berprestasi., 3) sistem pembayaran kompensasi dosen STAI Ma'arif Sarolangun sudah sesuai dengan prosedur, miskipun jumlah nominal Rupiah (Rp) yang diterima dosen masih dikategori rendah, jika dibandingkan dengan dosen STAI lain di bawah lingkungan Kopertai wilayah XIII Provinsi Jambi.
\end{abstract}

Kata Kunci: Pemberian Kompensasi, Kinerja Dosen

Nur El-Islam, Volume 7, Nomor 1, April 2020 


\section{A. Pendahuluan}

Werther dan davis, menjelaskan tentang kompensasi adalah Compensation is what employee reselve in exchange of their work, whether huoly wages or periodic salaries, the personnel department usualy designs and administersemployee compensation. Hal ini dimaksudkan bahwa kompensasi apa yang seorang pekerja terima sebagai balasan dari pekerjaan yang diberikannya, baik upah per jam atau pun gaji periodik didesain dan dikelola oleh bagian personalia. ${ }^{1}$

Edwin B. Flippo, menjelaskan wages is defined as the adeguate and eguitable renumeration of personnel for thier cntribution to organizational objektives. Dimaksudkan bahwa upah diartikan sebagai balas jasa yang adil dan layak diberikan kepada para pekerja atas jasa-jasanya dalam mencapai tujuan organisasi. ${ }^{2}$

Hasibuan, kompensasi adalah semua pendapatan yang berbentuk uang, barang langsung atau tidak langsung yang diterima karyawan sebagai imbalan atas jasa yang diberikan kepada perusahaan. ${ }^{3}$ Pendapat lain dikemukakan oleh Simamora, kompensasi mengandung cakupan yang lebih luas dari pada sekedar pemberian upah dan gaji. Konsep upah lebih menekankan pada balas jasa yang lebih bersifat finansial sedangkan kompensasi mencakup balas jasa yang bersifat finansial maupun non finansial.

Kompensasi dibedakan menjadi dua yaitu; (1) kompensasi langsung (direc compensation) berupa gaji, upah, dan upah isentif, (2) kompensasi tidak langsung (indirec compensayion atau employee wefaree) atau kesejahteraan karyawan. ${ }^{4}$ Menurut Hadari Nawawi, Kompensasi adalah penghargaan/ganjaran pada para pekerja yang telah memberikan kontribusi dalam mewujudkan tujuannya, melalui

${ }^{1}$ Denis. Forcese and Stepher Richer, Social Research Methode, New Jesrsey (Prantice-Hall Inc.,Eglewood Cliffs, 2013), h. 234.

${ }^{2}$ Edwin B. Flippo. Personel Management (New York : Mc. Graw-Hill Book Company, 2014), h. 119.

${ }^{3}$ Malayu Hasibuan. Manajemen Dasar Pengertian dan Masalah. (Jakarta: Bumi Aksara, 2018). h. 118.

${ }^{4}$ Simamora. Manajemen Sumber Daya Manusia, (Yokyakarta: YKPN, 2017). h. 80. 
kegiatan yang disebut bekerja. Jenis-jenis kompensasinya sebagai berikut:

\section{Kompensasi Langsung}

Kompensasi langsung adalah penghargaan/ganjaran yang disebut gaji atau upah, yang dibayar secara tetap berdasarkan tengang waktu yang tetap. Sejalan dengan itu upah atau gaji secara tunai yang diperoleh pekerja untuk pelaksanaan pekerjaannya. Upah diartikan juga sebagai harga untuk jasa-jasa yang telah diberikan oleh seseorang kepada orang lain.

2. Kompensasi Tidak Langsung

Kompensasi tidak langsung adalah pemberian bagian keuntungan/manfaat lainnya bagi para pekerja di luar gaji atau upah, dapat berupa uang atau barang Misalnya THR, Tunjangan Hari raya, dan lain-lain.

3. Insentif

Insentif adalah penghargaan/ganjaran yang diberikan untuk memotivasi para pekerja agar produktivitas kerjanya tinggi, sifatnya tidak tetap atau sewaktu-waktu. Oleh karena itu insentif sebagai bagian dari keuntungan, terutama sekali diberikan pada pekerja yang bekerja secara baik atau yang berprestasi. Misalnya dalam bentuk pemberian bonus. Di samping itu insentif dapat pula diberikan dalam bentuk barang. Dalam manifestasinya dapat dibedakan antara kompensasi Total dan kompensasi Khusus yaitu:

a. Kompensasi Total

Kompensasi ini adalah keseluruhan penghargaan/ganjaran yang diterima oleh seorang pekerja untuk seluruh pekerjaan yang dilakukannya sebagai kontribusinya pada pencapaian tujuan organisasi. Komponennya terdiri dari ketiga jenis kompensasi tersebut di atas, yakni gaji/upah, beberapa jenis kompensasi tidak langsung dan insentif

b. Kompensasi Khusus

Kompensasi ini disebut juga penghasilan tambahan yakni pengahargaan/ganjaran yang diberikan kepada pekerja dengan status tertentu dalam organisasi. Kompensasi ini biasanya diberikan secara khusus untuk manajer tingkat atas. Bentuknya antara lain berupa 
kenderaan, tempat parkir, pembayaran uang anggota perkumpulan eksekutif untuk pertemuan dan olah raga dan lain-lain. ${ }^{5}$

Sementara Gibson mengatakan bahwa kinerja adalah merujuk pada tingkat kerberhasilan dalam melaksanakan tugas serta kemampuan untuk mencapai tujuan yang telah di tetapkan.Kinerja dinyatakan baik dan sukses jika tujuan yang ingin di capai dengan baik, terutama pada kualitas dan efisiensi dari kriteria keefektipan. ${ }^{6}$

Manjemen kinerja adalah suatu cara untuk mendapatkan hasil yang lebih baik organisasi, kelompok dan individu dengan memahami dan mengelola kinerja sesuai dengan target yang telah direncanakan, standar dan persyaratan kompetensi yang telah ditentukan. ${ }^{7}$ Penilaian kinerja pada kinerja individual yaitu: 1) penampilan; 2) disiplin dan ketaatan dan ketelitian; 3) pemauan dan kemampuan belajar; 4) hubungan dengan pelangan, bawahan, rekan kerja, dan atasan; 5) motivasi diri; 6) kecermatan dan ketelitian; 7) produktivitas/kecepatan dalam bekerja; 8) kualitas kerja; 9) pengetahuan dan keterampilan kerja; 10) kemampuan beradaptasi; 11) kemampuan bekerja sama dengan kerja Tim; 12) kemampuan mengatasi masalah; 13) kemampuan berkomunikasi lisan dan tulisan; 14) kemampuan memimpin dan mengorganisasi; 15 ) loyalitas. ${ }^{8}$

Kriteria pendekatan manjemen kinerja yang efektif dengan apa yang dibutuhkan oleh organisasi, manajer, dan karyawan untuk mencapai sukses yaitu:

1. Suatu cara untuk mengkoordinasikan kerja agar tujuan dan sasaran organisasi, unit kerja dan para karyawan dapat diarahkan pada titik yang sama

2. Suatu cara untuk mengidentifikasikan masalah dalam prosesproses yang menghalangi organisasi untuk menjadi lebih efektif

${ }^{5}$ Hadari Nawawi, Manajemen Sumber Daya Manusia untuk Bisnis Kompetitif (Yokyakarta, Gajah Mada Universitas Pres, 2018), h. 315-316.

${ }^{6}$ Gibson, James L et al, Organizations: Behavior, Structure, Processess, (America: McGraw-Hill, 2006), h. 25.

${ }^{7}$ Ibid. h. 25

${ }^{8}$ Martinis dan Maisah, Standarisasi Kinerja Guru (Jakarta: Gaung Persada, 2010), h. 33. 
3. Suatu cara untuk mendokumentasikan masalah-masalah kinerja untuk membantu organisasi memenuhi segenap peraturan dan ketentuan hukum ( dan menunjuk kepatuhan itu), untuk menghindari tuntutan ketidak puasan hukum, serta untuk digunakan sebagai bukti bilamana perlu.

4. Informasi untuk membuat keputusan-keputusan tentang promosi, strategi pengembangan karyawan dan pelatihan

5. Informasi agar manajer dapat mencegah terjadinya masalah, membantu para staf melakukan pekerjaan mereka, mengkoordinasikan kerja dan memberikan laporan kepada pimpinan mereka secara lengkap dan menguasai persoalan (agar mereka tidak tampak bodoh)

6. Suatu cara bagi manajer untuk bekerja sama dengan para karyawan, dalam mengidentifikasi wilayah permasalahan, mendiagnosis penyebabnya, dan mengambil tindakan untuk menyelesaikan masalah tersebut.

7. Suatu cara untuk mengkoordinir semua karyawan yang bertanggung jawab pada seseorang manajer yang sama.

8. Suatu metode untuk memberikan umpan balik secara berkala dan terus-menerus kepada para karyawan, dengan cara yang mendukung motivasi mereka.

9. Suatu cara untuk mencegah terjadinya kesalahan-kesalahan, dengan memberikan penjelasan tentang apa yang diharapkan dalam kerja, menenamkan pemehaman bersama tentang apa yang boleh dan yang tidak boleh dikerjakan sendiri oleh karyawan, serta menunjukan apa dan bagaimana kedudukan pekerjaan para karyawan itu dalam gambaran yang menyeluruh

10. Suatu cara untuk merencanakan berbagai aktivitas pengembangan diri dan pelatihan karyawan. ${ }^{9}$

Pengukuran kinerja merupakan alat untuk menilai kesuksesan organisasi. Dalam konteks organisasi sektor publik, kesuksesan organisasi itu akan digunakan untuk mendapatkan legitimasi dan

\footnotetext{
${ }^{9}$ Robert Bacal, Performance Management (Jakarta: Gramedia Pustaka Utama, 2015), h. 25.
} 
dukungan publik. Masyarakat akan menilai kesuksesan organisasi sektor publik melalui kemampuan organisasi dalam memberikan pelayanan publik yang relatif murah dan berkualitas. ${ }^{10}$

Pengukuran Kinerja merupakan bagian penting dari proses pengedalian Manajemen, baik organisasi publik maupun swasta. Tujuan dilakukannya penilaian kinerja di sektor Publik adalah :

1. Mengetahui tingkat ketercapaian tujuan organisasi.

2. Amenyediakan sarana pembelajaran Pegawai

3. Memperbaiki kinerja periode berikutnya.

4. Memberi pertimbangan yang sistematis dalam pembuatan keputusan pemberian Reward dan punishment.

5. Memotivasi pegawai

6. Menciptakan akuntabilitas publik ${ }^{11}$

Berdasarkan pengertian dan teori tentang kinerja dan pengukuran kinerja maka dapat disintesiskan bahwa kepuasan kerja adalah perasaan seseorang dosen mengenai pekerjaanya yang ditandai dengan pekerjaan yang ditekuni, kualitas pengawasan, hubungan dengan rekan dan kesempatan promosi

Sumberdaya manusia yang berkualitas merupakan salah satu modal dasar pembangunan. Upaya peningkatan dan pengembangan sumber daya manusia telah menjadi persyaratan utama bagi Bangsa Indonesia untuk bebas bersaing dalam percaturan dunia yang menglobal pada mellenium ke tiga. Untuk menghadapi tantangan yang menglobal pemerintah merupakan unsur terpenting dalam pemerintahan yang dituntut senantiasa terbuka, jujur, transparan dan mampu menjaga akuntabilitas dalam proses kerja, baik ke dalam maupun ke luar negeri. Untuk itu sumber daya berkualitas dan handal sangat penting maknanya bagi pembangunan nasional bahkan dapat di katakan bahwa masa depan bangsa terletak pada kesadaran lembaga yang berkualitas akan muncul apabila individu-individunya berkualitas dan memiliki etika kerja yang optimal.

${ }^{10}$ Mahmudi, Manajemen Kinerja Sektor Publik (Yogyakarta: YKPN, 2015), h. 12.

${ }^{11}$ Ibid. h. 14. 
Manajemen Sumber Daya manusia adalah suatu ilmu atau cara bagaimana mengatur hubungan dan peranan sumber daya (tenaga kerja) yang dimiliki oleh individu secara efisien dan efektif serta dapat digunakan secara maksimal sehinga tercapai tujuan bersama organisasi, karyawan dan masyarakat menjadi maksimal. Manajemen Sumber Daya Manusia di dasari pada konsep bahwa setiap karyawan adalah manusia, bukan bisnis. Kajian manajemen Sumber Daya Manusia mengabungkan beberapa bidang ilmu seperti psikologi, sosiologi, dan lain-lain.

Stoner mengemukakan bahwa manajemen Sumber Daya Manusia adalah suatu prosedur yang berkelanjutan yang bertujuan untuk memasok suatu organisasi dengan orang-orang yang tepat untuk ditempatkan pada posisi dan jabatan yang tepat pada saat organisasi memerlukannya.

Sedarmayanti, Kualitas dan kuantitas sumber daya manusia dalam suatu organisasi hendaknya disesuaikan dengan kebutuhan organisasi yang bersangkutan supaya efektif dan efisien dalam menunjang tercapainya tujuan. Penepatan pegawai atau karyawan juga harus disesuaikan dengan keinginan dan keterampilannya, sehingga gairah kerja dan kedisplinannya akan lebih baik, serta efektif dalam menunjang terwujudnya tujuan organisasi. ${ }^{12}$ Triton, Produktivitas dan kinerja adalah bagian yang harus diperhatikan dalam Manajemen Sumber Daya Manusia (SDM). Manejer yang sukses harus memiliki kemampuan dalam meningkatkan kinerja dan produktivitas karyawannya. Keduanya sangat berperan penting dalam menentukan keberlangsungan kegiatan wirausaha maupun kerjanya. ${ }^{13}$

Sastradipeora yang di kutif oleh Budiman Suhardiman, manajemen Sumber Daya Manusia bisa di pandang sebagai seni, suatu disiplin, suatu proses, suatu sub disiplin, dan salah satu pendekatan dalam ilmu manajemen. Sebagai suatu seni, manajemen sumber daya manusia erat kaitannya dengan memilih personalia baru dan

12 Sedarmayanti, Sumber Daya Manusia dan Produktivitas Kerja (Bandung: Mandar Maju, 2017), h. 9.

${ }^{13}$ Triton PB, Mengelola Sumber daya manusia, (Jakarta, Oryza. 2009), h. 79 
memperkerjakan personalia yang sudah tersedia agar dapar memperoleh hasil dan pelayanan yang maksimal. Manajemen sumber daya manusia sebagai suatu disiplin, erat kaitannya dengan mempelajari manusia dalam hubungan kerja dalam suatu organisasi. Yang di maksud disiplin yaitu suatu bidang kajian ilmu. Manajemen sumber daya manusia sebagai suatu proses, yaitu untuk memperoleh, mengembangkan, dan merawat pekerja sehingga mereka mendapat kecakapan dalam melaksanakan fungsi dan mencapai tujuan organisasi dengan efisien. Yang dimaksud proses dalam kontek ini yaitu suatu rangkaian fungsi, tindakan, pelaksanaan, atau perubahan yang bergerak untuk mencapai suatu tujuan. Manajemen sumber daya manusia sebagai suatu subdisiplin, artinya bahwa manajemen sumber daya manusia merupakan cabang dari ilmu manajemen yang mengkaji seluruh proses penggunaan tenaga manusia sejak mereka diterima sampai diberhentikan. Manjemen sumber daya manusia adalah pendekatan yang lengkap, terencana, terbimbing, dan terawasi terhadap penarikan, pengembangan, pemberian kontraprestasi (konpensasi), pengintegrasian, perawatan, dan pemutusan hubungan kerja. ${ }^{14}$

Berdasarkan konsep tersebut diatas dapat disimpulkan bahwa manjemen sumber daya manusia merupakan suatu proses pengelolaan sumberdaya manusia secara efektif dan efisien serta dapat menempatkan posisi karyawan sesuai dengan keahlian yang mereka miliki, dalam rangka mencapai suatu tujuan organisasi. Selain itu, manajemen sumber daya manusia juga dapat menunjang aktivitas organisasi.

Komitmen organisasi menunjukkan bahwa seseorang secara internal menyetujui dan membuat suatu upaya yang besar untuk melaksanakannya. Hal ini menunjukkan bahwa komitmen dalam bertindak sesuai dengan tujuan pribadi dan tujuan organisasinya, akan dapat memperlancarkan tercapainya tujuan organisasi dan sekaligus meningkatkan kinerja pegawai. Keyakinan inilah yang dikatakan

${ }^{14}$ Budiman Suhardiman, Pengembanagan Sumber Daya Manusia (Bandung: Alfabeta, 2017), h. 207. 
sebagai kesetiaan terhadap organisasi atau komitmen organisasi. Pegawai yang memegang teguh komitmen organisasinya akan jelas dalam melaksanakan tugasnya terarah dan memiliki kinerja yang tinggi.

Namun perilaku pegawai sekarang ini banyak mendapat kritikan dari masyarakat, karena upaya kerja pergawai sebagai sumber daya manusia yang handal ternyata belum dapat dikatakan berhasil dengan baik, hal ini dikarenakan banyak persoalan moral pegawai yang dituding mulai dari pegawai kecil sampai pada pejabat-pejabat struktural dan fungsional di antaranya masalah kedisiplinan kerja. Keterkaitan dengan masalah tersebut dianggap sangat serius di mana para pegawai tidak masuk kantor atau masuk tidak tepat waktu yang ditentukan, kurang disiplin dalam menangani pekerjaan, atau sistem penempatan pegawai yang tidak sesuai dengan latar belakang pendidikan, sehingga saling menyalahkan dan masih banyak persoalan lainnya yang berhubungan dengan aturan yang telah ditetapkan oleh lembaga/Instansi.

Keberhasilan suatu organisasi dalam melaksanakan fungsifungsi organisasi sangat tergantung pada strategi atau sistem pelaksanaan manajemen organisasi dalam peningkatan kualitas organisasi secara terus-menerus perlu diperhatikan.

Berdasarkan studi pendahuluan (grand tour) penulis di STAI Ma'arif Sarolangun, di temukan ketidak teraturan sistem pemberian kompensasi dosen. Hal ini terindikasi empat semester dosen selesai mengajar pemberian kompensasi baru di berikan, itupun dibayar bertahap dan tidak langsung dibayar secara keseluruhan. Selain itu, kompensasi membimbing mahasiswa, juga dibayar tidak menentu. Hal ini tentu menjadi salah satu faktor penyebab rendahnya kinerja dosen dalam melaksanakan tugas mengajar. Maka dari itu, permasalahan ini menjadi suatu kajian yang menarik untuk di teleti secara lebih mendalam, mengapa kurang optimalnya pemberian kompensasi dosen di STAI Ma'arif Sarolangun?. Dengan demikian, yang menjadi sub pokok bahasan dalam penelitian ini adalah sebagai berikut: Bagaimana bentuk pemberian kompensasi dosen di STAI 
Ma'arif Sarolngun?, Bagaimana sistem pemberian kompensasi dosen di STAI Ma'arif Sarolangun ?.

Tujuan Penelitian: a. Ingin mengetahui perencanaan pemberian kompensasi dosen di STAI Ma'arif Sarolangun , b. Ingin mengetahui pelaksanaan pemberian kompensasi di STAI Ma'arif Sarolngun, c. Ingin mengetahui upaya pimpinan untuk meningkatkan kinerja dosen di STAI Ma'arif Sarolangun. Sementara itu, manfaat penelitian, secara Teoritis, 1) dapat mengemukakan bentuk pemberian kompensasi yang di lakukan pimpinan untuk meningkatkan kinerja dosen di STAI Ma'arif Sarolangun, 2) hasil penelitian ini dapat menjadi pedoman bagi pimpinan untuk meningkatkan kinerja dosen di STAI Ma'arif Sarolangun . Sedangkan secara Praktis adalah 1) Penelitian ini dapat di jadikan bahan masukan bagi pimpinan STAI Ma'arif Sarolangun

Fokus pembahasan dalam penelitian hanya pada Sistem pemberian kompensi dan kinerja dosen mengajar di STAI Ma'arif Sarolangun, dengan alasan bahwa pemberian kompensasi merupakan suatu hal yang sangat penting untuk meningkatkan kinerja dosen mengajar. Karena pemberian kompensasi tepat pada waktunya dapat memberi motivasi kepada dosen untuk lebih semangat mengajar. Oleh karena itu, peneliti ingin meneliti secara lebih mendalam apaapa saja bentuk kompensasi dan faktor penyebab kompensasi dosen tidak di bayar tepat waktunya.

\section{B. Metodologi Penelitian}

Dalam penelitian ini, peneliti menggunakan pendekatan kualitatif-naturalistik. Melalui pendekatan kualitatif ini, di harapkan terangkat gambaran mengenai budaya yang di lakukan oleh pimpinan STAI Ma'arif Sarolangun dalam pemberian kompensasi kepada dosen. Pendekatan naturalistik menuntut pengumpulan data pada setting yang alamiah. Dengan konsep tersebut peneliti mengupayakan agar kehadiran peneliti tidak merubah situasi atau perilaku orang yang di teliti. Adapun metode dalam pengumpulan data dilapangan yaitu dengan metode observasi, wawancara dan dokumentasi. 


\section{Pembahasan}

\section{Bentuk Kompensasi Dosen di STAI Ma'arif Sarolangun}

Menurut Peraturan Menteri Riset dan Teknologi dan Pendidikan Tinggi RI No. 20 Tahun 2017 tentang Pemberian tunjangan profesi dosen dan tunjangan kehormatan profesor, pasal 2 dan 3 berbunyi:

Pasal 2, tunjangan profesi diberikan kepada dosen yang memiliki jabatan akademik Asisten ahli, lektor kepala, dan profesor. Pasal 3, ayat 1 berbunyi; tunjangan profesi diberikan kepada dosen sebagaimana di maksud dalam pasal 2, apabila memenuhi persyaratan: a) memiliki sertifikasi pendidik yang diterbitkan oleh Kementerian, b) melaksanakan tridarma Perguruan Tinggi dengan beban kerja paling sedikit sepadan dengan 12 (dua belas) sks dan paling banyak sepadan dengan 16 (enam belas) sks pada setiap semester dengan ketentuan; (1) beban kerja pendidik dan penelitian paling sedikit sepadan dengan 9 (sembilan) sks yang dilaksanakan di perguran tinggi yang bersangkutan dan, (2) beban kerja pengabdian masyarakat dapat dilaksanakan melalui kegiatan pengabdian yang diselengarakan oleh perguruan tinggi yang bersangkutan atau melalui lembaga lain. ${ }^{15}$

Makna permen tersebut di atas, dapat dipahami bahwa pemberian kompensasi dosen di bayar sesuai dengan beban kerja dosen. Kompensasi adalah imbalan berupa uang atau ukan uang (natural) yang diberikan kepada karyawan dan dosen dalam suatu organisasi (PT).

Berdasarkan hasil data observasi yang dapat peneliti himpun di STAI Ma'arif Sarolangun ada beberapa bentuk kompensasi dosen yang diberikan oleh Ketua STAI : 1) kompensasi honor mengajar, 2) kompensasi pembimbing Skripsi. Kompensasi menjadi pembimbing PPL, 3) Kompensasi pembimbing Kukerta mahasiswa, 4) konpensasi menguji proposal, dan ujian Skripsi. Namun peneliti tidak menemukan

${ }^{15}$ Kemenristek Dikti, Peraturan Menteri Riset dan Teknologi dan Pendidikan Tinggi RI No. 20 Tahun 2017 tentang Pemberian tunjangan profesi dosen dan tunjangan kehormatan profesor (Jakarta, Kemenristek Dikti Press, 2017), h. 1. 
adanya kompensasi yang berbentuk barang pakain, penghargaan lain terhadap dosen.

Hasil pengamatan peneliti tersebut diatas sesuai dengan hasil wawancara peneliti dengan salah seorang pembantu ketua I STAI Ma'arif yang berinisial RF mengatakan bentuk kompensasi dosen yang ada di STAI Ma"arif ini cukup banyak, contoh ada honor mengajar dosen yang dibayar sesuai jumlah SKS mengajar, ada juga kompensasi menjadi peguji mahasiswa Skripsi mulai dari seminar proposal sampai ujian munaqasah, menjadi pembimbing PPL dan Kukerta mahasiswa. Selain itu, memang diakui bahwa yang berbentuk barang selama ini belum ada, kerna STAI belum sanggup untuk memberi kompensasi seperti itu.

Pendapat lain juga dikemukakan oleh salah seorang dosen STAI Ma'arif Sarolangun yang berinisial SP mengatakan memang ada beberapa bentuk kompensasi dosen yang diberikan oelh ketua STAI Ma'arif Sarongun yaitu honor mengajar, kompensasi menguji proposal sampai ujian Skripsi dan ada juga kompensasi menjadi pembimbing PPL dan Kukerta mahasiswa. Namun saya belum melihat adanya bentuk kompensasi lain seperti barang yang diberikan kepada dosen. Menginggat STAI Ma'arif pembiayaannya 100\% dari sumbernya SPP mahasiswa yang masih sedikit.

Pernyataan Dosen tersebut diatas diperkuat oleh Bendahara yang berinisial $\mathrm{BH}$ mengatakan terkait dengan kompensasi yang diberikan Ketua STAI Ma'rif Sarolangun kepada dosen dalam meningkatkan kinerja, memang ada beberapa bentuk kompensasi seperti kompensasi honor mengajar, kompensasi menguji proposal sampai ujian Skripsi, kompensasi menjadi pembimbing kukerta mahasiswa, kompensasi menjadi pembimbing PPL dan ada juga kompensasi kegiatan wisuda mahasiswa. Akan tetapi memang diakui bahwa bentuk kompensasi berupa barang yang diberikan kepada dosen, ketua STAI Ma'rif Sarolangun belum mampu untuk memberinya. Meninggat ada beberapa pembiayaan operasional lain yang harus dilaksanakan.

Berdasarkan hasil observasi dan interviu peneliti tersebut diatas dapat dipahami dan disimpulkan bahwa bentuk kompensasi dosen 
yang diberikan Ketua STAI Ma'rif Sarolangun dalam rangka meningkatkan kinerja dosen sudah ada beberapa bentuk kompensasi, namun belum ada bentuk kompensasi yang berbentuk barang sebagai wujud penghargaan kepada dosen yang terindikasi berprestasi. Hal ini terkait dengan pembiayaan yang ada di STAI Ma'arif Sarolangun masih dikategori minim sementara kebutuhan operasional lain yang sangat penting untuk dilaksanakan dengan pembiyaan ada.

\section{Sistem Pemberian Kompensasi di STAI Ma'arif Sarolangun}

Menurut Hasibuan, Tujuan pemberian kompensasi (balas jasa) antara lain adalah sebagai ikatan kerja sama, kepuasan kerja, pengadaan efektif, motivasi, stabilitas karyawan, disiplin, serta pengaruh serikat buruh dan pemerintah. Gaji adalah balas jasa yang dibayar secara periodik kepada karyawan tetap serta mempunyai jaminan yang pasti. Maksudnya, gaji akan tetap dibayar walaupun pekerja tersebut tidak masuk kerja. Upah adalah balas jasa yang dibayarkan kepada pekerja harian dengan berpedoman atas perjanjian yang disepakati membayarnya. Sedangkan upah isentif adalah tambahan balas jasa yang diberikan kepada karyawan tertentu yang prestasinya di atas prestasi standar Benefit dan service adalah kompensasi tambahan (financial atau non financial) yang diberikan berdasarkan kebijaksanaan pemimpin terhadap semua karyawan dalam usaha untuk meningkatkan kesejahteraan mereka. Seperti tunjangan hari raya, uang pensiun, pakaian dinas, mushalla, olahraga, dan darmawisata. ${ }^{16}$

Berdasarkan teori tersebut diatas, peneliti membandingkan dengan fakta yang dapat dihimpun melalui hasil pengamatan peneliti terkait dengan sistem pemberian kompensasi yang dilakukan oleh Ketua STAI Ma'rif Sarolangun kepada dosen yang ada di STAI, ada beberapa 1) Sistem pembayaran honor mengajar dibayar 6 bulan sekali setelah mahasiswa ujian semester, artinya satu tahun dibayar 2 kali, 2) Sistem pembayaran penguji proposal, langsung dibayar setelah mahasiswa selesai ujian proposal, begitu juga ujian skripsi, 4) Sistem

${ }^{16}$ Hasibuan, Manajemen Dasar Pengertian, h. 188. 
pembayaran kompensasi menjadi pembimbing kukerta dan PPL mahaisiswa juga dibayar langsung sebelum mengatar mahasiswa ke lapangan. Artinya jika dibandingkan dengan teari tersebut diatas Ketua STAI Ma'rif Sarolangun sudah mengikuti teori yang dibagun, yaitu membayar upah atau gaji karyawan sebelum keringatnya keluar.

Hasil pengamatan peneliti tersebut diatas, diperkuat oleh pernyataan Pembantu ketua 2 bidang Administrasi perencanaan dan keuangan STAI Ma'rif Sarolngun yang berinisial FR mengatakan bahwa sistem pembayaran kompensasi dosen yang ada di STAI Ma'arif Sarolangun sudah sesuai dengan prosedurnya. Miskipun jumlah angka yang diterima masing-masing dosen masih dikategori rendah, jika dibandingkan dengan kompensasi dosen perguruan Tinggi Swasta lainnya dibawah lingkungan Kopertais wilayah XIII Provinsi Jambi. Namun sebagai STAI yang baru berkembang cukup memberi motivasi kepada dosen untuk meningkatkan kinerjanya di STAI Ma'arif Sarolangun.

Pernyataan lain juga di kemukakan oleh salah seorang dosen yang berinisial FZ mengatakan terkait dengan sistem pembayaran kompensasi dosen dalam meningkatkan motivasi kinerja dosen di STAI Ma'arif Sarolangun, sudah cukup meningkat jika dibandingkan dari zaman mulai saya mengajar tahun 2009 sampai sekarang. Dulu mengajar lebih banyak ihklas beramal, karena STAI Ma'arif belum banyak dikenal oleh masyarakat Kabupaten Sarolangun, Jadi mahasiswa sangat sedikit. Tapi sekarang alhamdulillah jumlah mahasiswanya sudah cukup banyak kurang lebih sudah berjumlah 700 orang. Maka dari itu, sistem pembayaran kompensasi mengajar diberi setiap 6 bulan sekali setelah mahaisiswa ujian semerter. Namun kompensasi menguji, membimbing dan sebagainya itu, dibayar langsung setelah pelaksanaan kegiatan berakhir.

Pernyataan FZ tersebut diatas, di perkuat oleh Ketua STAI Ma'arif Sarolangun yang berinisial MD mengatakatan masalah sistem kompensasi dosen yang ada di STAI ini, alhamdulilah sudah cukup memberi motivasi dosen untuk meningkatkan kinerjanya, terutama dalam bidang mengajar. Sistemnya jika dosen tersebut menguji proposal dan Skripsi, kompensasinya langsung dibayar setelah 
melaksanakan kegiatan, jika dosen tersebut menjadi dosen pembimbing PPL dan kukerta sistem pembayarannya, dibayar terlebih dahulu sebelum kegiatan dilaksanakan. Karena dosen tersebut akan mengantar mahasiswa kelokasi. Akan tetapi kompensasi lain yang berbetuk barang, saya akui belum ada, menginggat kecukupan dari pembayaran kompensasi itu dana STAI masih minem.

Berdasarkan hasil observasi dan interviu tersebut diatas, dapat dipahami bahwa sistem pembayaran kompensasi dosen yang mengajar di STAI Ma'rif Sarolangun sudah sesuai dengan prosedurnya, miskipun jumlah angka yang diterima oleh masing-masing dosen masih dikategorikan sangat rendah jika dibandingkan dengan kompensasi dosen yang mengajar di STAI Swasta lainnya dibawah Lingkungan Kopertais XIII Provinsi Jambi. Maka itu, Ketua STAI Ma'arif Sarolangun sangat menyadari bahwa kompensasi yang diterima dosen sebagai balas jasa baik mengajar maupun membimbing masih rendah., pun begitu pula tentang pemberian kompensasi lain seperti barang sebagai penghargaan kepada dosen belum ada untuk meningkatkan kinerja dosen.

\section{Upaya yang di Lakukan Ketua STAI Ma'arif Sarolangun untuk Meningkatkan Kinerja Dosen}

Armstrong, menjelsakan human resource management is defined as a strategic and coherent approach to the management of an organization's most valued assets the people working there who individually and collectively contribute to the achievement of its objektives. (Pengelolaan sumber daya manusia didefinisikan sebagai pendekatan strategis dan koheren pada pengelolaan aset organisasi yang paling berharga, orang-orang yang bekerja disana yang secara individual dan kolektif memberikan kontribusi pada pencapaian tujuan. ${ }^{17}$

Berdasarkan konsep tersebut di atas dapat dipahami bahwa sangat urgensi Ketua STAI Ma'arif Sarolangun untuk memberi motivasi kepada seluruh sumber daya manusia yang bekerja di STAI.

${ }^{17}$ Armstrong, Michael, Managing People A Pratical Guide For Line Managers (New York: Holt, Rinehart and Winston 2018). h, 3. 
Karena SDM yang bekerja adalah merupakan aset untuk membantu pengembangan STAI ke depan. Oleh karena itu, terkait dengan penigkatan kompensasi merupakan suatu upaya strategis yang perlu di lakukan oleh Ketua STAI Ma'arif untuk meningkatkan semangat dosen mengajar. Sesuai dengan hasil interviu peneliti dengan Ketua STAI Ma'arif yang berinisial MD mengatakan ada beberapa upaya yang dapat dilakukan untuk peningkatan kompensasi dosen yaitu 1) upaya untuk mempromosi STAI Ma'arif Sarolangun secara lebih inten kepada masyarakat, agar orang tua termotivasi untuk melanjutkan pendidikan anaknya ke STAI, karena jika jumlah mahasiswa cukup banyak, sudah barang tentu kompensasi dosen mengajar juga bisa ditingkatkan, 2) berupaya untuk memberi kompensasi yang berbentuk lain kepada dosen, atau memberi pembiayaan penigkatan kompetensi kualifikasi dosen untuk S3. ${ }^{18}$

Pernyataan Ketua STAI Ma'arif tersebut diperkuat oleh salah pembantu ketua I berinisial FR mengatakan masalah peningkatan kompensasi dosen kedepan, memang ada beberapa upaya yang akan dilakukan oleh pihak pimpinan STAI, baik peningkatan dalam bidang finansial maupun dalam bidang lain yang bisa memberi motivasi kepada dosen dalam meningkatkan kinerjanya. Meninginggat kompensasi itu sangat penting untuk diperhatikan oleh pimpinan, karena timbulnya semangat mengajar dosen itu tinggi yaitu dengan adanyan kompesasi tinggi yang akan diterimanya setelah dia mengajar. Maka dari itu, sebagai pimpinan akan berupaya dengan semaksimal mungkin kedepan bisa untuk meningkatkan kompensasi dosen. ${ }^{19}$

Pernyataan lain juga dikemukakan oleh pembatu ketua II STAI Ma'arif Sarolangun yang berinisial FH mengatakan bahwa sebagai pimpinan yang khusus mengurus malasalah keuangan di STAI Ma'arif ini, tetap terus berupaya dalam rangka meningkatan kompensasi dosen setiap tahunnya sesuai dengan kemampuan pembiayaan yang

${ }^{18}$ Observasi di STAI Ma'arif Sarolangun, tanggal 14 September 2019

${ }^{19}$ Wawancara dengan FR, Wakil Ketua I STAI Ma'arif Sarolangun, tanggal 14 September 2019 
ada di STAI. Alhamdulilah dari tahun ketahun jumlah mahasiswa sudah semangkin meningkat, setiap jumlah mahasiswa meningkat tentu saja pembiayaan juga otomatis meningkat. Namun tidak bisa dipungkiri bahwa STAI Ma'arif Sarolangun baru akan berkembang seperti STAI-STAI lain yang ada dibawah naugan Kopertais Wilayah XIII Provinsi Jambi. ${ }^{20}$

Berdasarkan hasil Interviu peneliti tersebut diatas, sesuai dengan hasil pengamatan peneliti berikut ini, bahwa pimpinan memang terlihat akan berupaya untuk menigkatkan kompensasi dosen baik mengajar maupun dalam bidang kompensasi lain. Selain itu, peneliti juga melihat pimpinan STAI ke depan akan berupaya untuk memberi kompensasi kepada dosen dengan cara peningkatan kompetensi kualifikasi dosen dari S2 ke S3. Hal ini dilakukan tidak terlepas dari tuntutan borang akreditasi dan juga merupakan kompensasi dosen yang sangat berharga baik untuk diri dosen itu sendiri maupun untuk STAI Ma'arif Sarolangun.

Hasil interview dan pengamatan peneliti tersebut di atas, dapat peneliti mengambil kesimpuan bahwa Ketua STAI akan berupaya kedepan untuk memberi kompensasi kepada dosen sesuai dengan pembiayaan yang ada di STAI Ma'arif Sarolangun. Menurut peneliti kompensasi yang diberikan adalah merupakan balas jasa yang diberikan oleh Ketua STAI kepada dosen yang mengajar di STAI. Mengingat kemajuan suatu lembaga sangat di butuhkan kontribusi SDM yang ada didalamnya yaitu dosen. Semangat kinerja dosen akan tumbuh tinggi, apabila didukung dengan kompensasi yang sesuai dengan keringatnya dan dibayar sebelum keringatnya keluar. Maka dari itu, perhatian kompensasi dosen oleh pimpinan sangat penting diperhatikan dan ditingkatkan.

\section{Kesimpulan}

Berdasarkan urain tersebut diatas, dapat peneliti mengambil kesimpulan sebagai berikut 1) Ada beberapa bentuk kompensasi dosen

${ }^{20}$ Wawancara dengan FH Wakil Ketua II STAI Ma’arif Sarolangun, tanggal 14 September 2019 
yang diberikan oleh ketua STAI Ma'arif Sarolangun seperti kompensasi honor mengajar, 2) kompensasi menguji mahasiswa proposal dan ujian skripsi, 3) kompensasi membimbing mahasiswa PPL dan Kukerta. Namun belum ada kompensasi yang berbentuk barang sebagai wujud penghargaan yang diberikan kepada dosen terindikasi berprestasi. Adapun Sistem pemberian kompensasi dosen di STAI Ma'arif Sarolangun sudah sesuai dengan prosedur. Meskipun masih dikategori jumlah nominal Rupiah (Rp) yang diterima oleh masingmasing dosen masih tergolong rendah, jika dibandingkan dengan kompensasi yang diterima oleh dosen STAI lain dibawah Lingkungan Kopertais Wilayah XIII Provinsi Jambi.

\section{Daftar Pustaka}

Armstrong, Michael, Managing People A Pratical Guide For Line Managers, New York: Holt, Rinehart and Winston 2018.

Denis, Forcese and Stepher Richer, Social Research Methode, New Jesrsey, Prantice-Hall Inc.,Eglewood Cliffs, 2017

Flippo. B. Edwin, Personel Management, New York: Mc. Graw-Hill Book Company, 2014

Gibson, James L et al, Organizations: Behavior, Structure, Processess, America, McGraw-Hill, 2016

Hadari Nawawi, Metode penelitian Bidang Sosial, Yokyakarta: gajah Mada, 2018

Hasibuan Malayu, Manajemen Dasar Pengertian dan Masalah. Jakarta: Bumi Aksara, 2016.

Mahmudi, Manajemen Kinerja Sektor Publik, Yogyakarta, YKPN, 2015

Martinis dan Maisah, Standarisasi Kinerja Guru, Jakarta: Gaung Persada, 2010 
Peraturan Menteri Riset dan Teknologi dan Pendidikan Tinggi RI No. 20 Tahun 2017 tentang Pemberian tunjangan profesi dosen dan tunjangan kehormatan profesor, Jakarta, 2017

Robert Bacal, Performance Management, Jakarta: Gramedia Pustaka Utama, 2015

Sedarmayanti, Sumber Daya Manusia dan Produktivitas Kerja, Bandung, Mandar Maju, 2017

Simamora, Manajemen Sumber Daya Manusia, Yokyakarta: YKPN, 2017.

Triton PB, Mengelola Sumber daya manusia, Jakarta, Oryza. 2017 